\title{
PENGGUNAAN HANDOUT TERHADAP HASIL BELAJAR SISWA PADA KONSEP KELARUTAN DAN HASIL KALI KELARUTAN DI SMAN 6 BANDA ACEH
}

\author{
Riska Imanda ${ }^{1 *}$, Sirry Alvina ${ }^{2}$, Sri Setiawaty ${ }^{3}$, dan Rita Hartati ${ }^{4}$ \\ ${ }^{1,2,3}$ Program Studi Pendidikan Kimia, Universitas Malikussaleh \\ ${ }^{4}$ Program Studi Teknik Industri, Universita Teuku Umar \\ *Email: riska.imanda07@unimal.ac.id
}

\begin{abstract}
Abstrak
Penelitian ini bertujuan untuk melihat perbedaan hasil belajar siswa yang belajar dengan menggunakan handout dengan yang tidak menggunakan handout. Perbedaan hasil belajar antara kelas kontrol dan eksperimen dapat dilakukan dengan menggunakan jenis penelitian deskriptif dan pendekatan kuantitatif. Sampel dipilih secara purposive sampling yaitu berdasarkan hasil uji homogenitas dan normalitas data hasil ujian harian. Pengumpulan data dilakukan dengan menggunakan soal pilihan ganda. Analisis menggunakan statistik uji-t yang terlebih dahulu diuji normalitas (Chi-Kuadrat $\left(\chi^{2}\right)$ dan uji homogenitas data (uji F). Hasil pengujian data berdistribusi normal dan homogen. Pengujian hipotesis menggunakan uji-t diperoleh $t_{\text {hitung }}=3,11$ dan $t_{\text {tabel }}=$ 2,02 pada $\alpha 5 \%$, jadi $\mathrm{t}_{\text {hitung }} \geq \mathrm{t}_{\text {tabel. }}$. Hasil uji statistis yang telah dilakukan maka dapat disimpulkan bahwa terdapat perbedaan hasil belajar antar kelas kontrol dan kelas eksperimen.
\end{abstract}

Kata kunci: handout, hasil belajar, deskriptif.

\section{Abstract}

This study aims to see the differences in student learning outcomes between those who are taught using handouts and those who are taught without handouts. The difference in learning outcomes between the control and experimental classes can be done using descriptive research types and quantitative approaches. The sample was selected by purposive sampling. It was based on the results of the homogeneity and normality test of the daily test results. The data were collected using multiple choice questions. The analysis used the t-test statistic which was first tested for normality (Chi-Square $\left(\chi^{2}\right)$ and data homogeneity test ( $F$ test). The results of data testing were normally distributed and homogeneous. Hypothesis testing using the $t$-test obtained $t$ count $=3.11$ and $t$ table $=2.02$ at $\alpha 5 \%$, so t count $\geq t$ table. From the results of statistical tests that have been carried out, it can be concluded that there are differences in learning outcomes between the control class and the experimental class.

Keywords: handouts, learning outcomes, descriptive.

\section{PENDAHULUAN}

Ilmu kimia merupakan suatu ilmu yang sangat menarik untuk dipelajari, akan tetapi karena teorinya bersifat abstrak sebagian besar siswa menganggap pelajaran kimia sulit dan membingungkan. Permasalahan dalam kegiatan belajar mengajar diantaranya seringkali seorang siswa tidak dapat memahami konsepkonsep dasar dengan kuat. Pembelajaran kimia merupakan sebuah pembelajaran yang pada dasarnya sangat menarik jika guru menggunakan strategi pembelajaran yang tepat saat proses belajar mengajar (Agustina, dkk., 2013). Proses belajar mengajar mata pelajaran kimia menuntut seorang pengajar mempunyai strategi yang tepat dalam melaksanakan kegiatan belajar mengajar, sehingga akan merangsang siswa untuk lebih aktif ketika kegiatan belajar 
mengajar berlangsung. Hal tersebut sesuai dengan tuntutan kurikulum yang mengharuskan siswa lebih aktif atau dikenal dengan student center, guru hanya berperan sebagai motivator (Situmorang dan Situmorang, 2014). Proses pembelajaran menuntut seorang pengajar mempunyai strategi yang tepat dalam melaksanakan kegiatan pembelajaran, idealnya rancangan pembelajaran yang dibuat harus melibatkan siswa aktif dalam proses berpikir diskusi dan aktivitas lain yang sejalan dan sesuai dengan tujuan pembelajaran yang akan dicapai sehingga menyebabkan aktivitas dan hasil belajar siswa dapat meningkat (Brahmantara dkk., 2013).

Nilai mata pelajaran kimia siswa rendah terlihat dari hasil ulangan harian tiga tahun terakhir dimana banyak siswa yang tidak bisa mencapai kriteria ketuntasan minimal (KKM). Patokan KKM untuk tiga tahun terakhir berturut-turut yaitu 65 . Nilai ulangan harian siswa yang tidak mencapai KKM untuk tiga tahun terakhir tersebut tergambar pada beberapa kompetensi dasar (KD) salah satunya yaitu KD 3.14 tentang memprediksi terbentuknya endapan dari suatu reaksi berdasarkan prinsip kelarutan dan hasil kali kelarutan. Nilai rata-rata hasil ulangan harian siswa yang tidak tuntas pada KD tersebut mulai tahun 2011, 2012 dan 2013 secara berturut-turut 45, 53, dan 50 .

Hal tersebut diperoleh peneliti ketika observasi (pengamatan) awal yang dilakukan di SMAN 6 Banda Aceh. Berdasarkan hasil observasi/wawancara yang dilakukan peneliti proses belajar mengajar yang berlangsung kurang efektif disebabkan bahan ajar yang digunakan kurang menarik, hanya fokus pada satureferensi, sehingga hasil belajar siswa rendah bahkan banyak dari siswa yang mendapatkan nilai dibawah KKM. Kondisi pembelajaran seperti ini akan sulit bagi guru untuk mencapai tujuan pembelajaran yang optimal. Untuk hasil belajar siswa ketika proses belajar mengajar bisa dilakukan berbagai variabel pembelajaran, salah satunya yaitu menerapkan bahan ajar, misalnya handout. Bahan ajar merupakan suatu bahan yang digunakan sebagai alat bantu dalam proses belajar mengajar.
Menurut Wena (2009), variabel pembelajaran yang berkaitan langsung dengan aktivitas dan hasil belajar siswa yaitu bahan ajar atau buku teks yang berkualitas. Ketersediaan buku teks yang berkualitas masih sangat kurang, akan menyebabkan siswa bosan karena pembahasan yang terlalu ringkas serta contoh soal yang tidak bervariasi sehingga menyebabkan hasil belajar dan aktifitas siswa rendah ketika proses belajar mengajar. Bahan ajar akan membantu siswa dalam mempelajari suatu kompetensi secara sistematis, sehingga siswa dapat menguasai suatu kompetensi secara terpadu. Bahan ajar handout merupakan jenis bahan ajar cetak (Majid, 2009). Lebih lanjut Siregar (2013) menyatakan bahwa handout berisi ringkasan materi dari beberapa literatur yang memiliki relevansi dengan materi yang diajarkan serta kompetensi dasar dan materi pokok yang harus dikuasai siswa, handout juga dilengkapi dengan soal-soal. Hartati (2013) mengemukakan bahwa penggunaan handout berbasis konstektual dapat mencapai ketuntasan klasikal. Selain hasil tes penggunaan handout berbasis konstektual juga dapat meningkatkan aktivitas siswa dan tergolong kategori sangat baik pada materi koloid dikelas XI SMA N 5 Banda Aceh. Lebih lanjut, Agustina dkk. (2013) mengemukakan bahwa metode pembelajaran jigsaw berbantuan handout dapat meningkatkan aktivitas dan prestasi belajar siswa pada materi hidrokarbon kelas $\mathrm{X}-\mathrm{C}$ SMAN 1 Gubug. Berdasarkan permasalahan dan beberapa hasil penelitian yang telah diuraikan diatas maka peneliti akan menerapkan handout pada materi kimia lain. Dalam penelitian ini peneliti ingin melihat perbedaan hasil belajar siswa yang menggunakan handout dengan siswa tanpa menggunakan handout, penelitian akan dilakukan pada materi kelarutan dan hasil kali kelarutan di SMAN 6 Banda Aceh dengan judul penelitian yaitu "Penggunaan Handout Terhadap Hasil Belajar Siswa pada Konsep Hasil Kali Kelarutan di SMAN 6 Banda Aceh". 


\section{METODE PENELITIAN}

Penelitian ini telah dilakukan di SMAN 6 Banda Aceh yang berlokasi di Jalan Tgk. Cot Aron Desa Lamjabat Kecamatan Meuraxa Kota Banda Aceh. Terpilihnya SMAN 6 Banda Aceh sebagai tempat penelitian berdasarkan nilai ulangan harian siswa pada 3 tahun terakhir tidak mencapai nilai KKM yang telah ditentukan dengan populasinya dalah kelas XI MIA. Penelitian ini menggunakan dua kelas sebagi sampel yang dipilih secara purposive sampling yaitu berdasarkan hasil uji normalitas dan uji homogenitas data hasil ujian harian sebelumnya. Sampel dalam penelitian ini yaitu kelas XI MIA 1 sebagai kelas eksperimen (menggunakan handout) dengan jumlah siswa (i) 26 dan kelas XI MIA 2 sebagai kelas kontrol (tanpa menggunakan handout) berjumlah 24 siswa (i). Penentuan kelas kontrol dan eksperimen tersebut didasarkan pada random sampling.

Penelitian ini menggunakan pendekatan kuantitatif dan jenis penelitian deskriptif. Data penelitian dikumpulkan menggunakan soal tes diberikan dalam bentuk soal-soal pilihan ganda berjumlah 14 soal yang telah divalidasi secara kualitatif yang meliputi materi, konstruk dan bahasa oleh dua orang validator. Soal tes juga dianalisis secara kuantitatif yang meliputi uji validasi (koefisien korelasi point biserial (rpbi)) dan uji reliabilitas (korelasi product moment). Hasil penelitian yang diperoleh dianalis menggunakan uji $\mathrm{t}$ (melihat perbedaan), sebelum melakukan uji t maka data hasil penelitian dianalisis dengan menggunakan uji t, tersebut terlebih dahulu diuji normalitas dengan menggunakan persamaan Chi-Kuadrat $(\chi 2)$ dan uji homogenitas dengan F. Analisis data yang digunakan berupa persentase hasil belajar siswa, dan uji signifikansi (hipotesis) dengan menggunakan uji t.

\section{HASIL DAN PEMBAHASAN}

Hasil penelitian ini diperoleh melalui soal tes sebagai hasil belajar siswa. Berdasarkan data hasil belajar yang diperoleh, dapat diuraian bahwa banyak siswa (i) yang tidak atau belum menguasai materi kelarutan dan hasil kali kelarutan tanpa menggunakan handout. Hal ni terlihat dari nilai siswa (i) yang masih rendah yaitu 15 dari 24 orang jumlah seluruh siswa (i) di kelas tersebut yang memiliki nilai di bawah standar KKM sekolah, berbeda halnya dengan kelas eksperimen yang menggunakan handout sebagai bahan ajar tambahan dalam proses pembelajaran. Dari hasil analisis data kelas eksperimen terdapat 5 dari 26 orang jumlah siswa yang tidak tuntas. Dari hasil yang diperoleh terlihat bahwa handout sebagai bahan ajar tambahan sangat efektif dan dapat mempengaruhi hasil belajar siswa. Bahan ajar tambahan dapat dijadikan media pembelajaran dapat meningkatkan kegiatan belajar kimia siswa dengan mudah dan efisien sehingga terjadi pergeseran pembelajaran dari teacher centre menuju student centre, sehingga dapat meningkatkan pencapaian hasil belajar siswa (Situmorang, 2013).

Penggunaan handout dapat menumbuhkan semangat belajar pada siswa (i) sehingga dapat meningkatkan hasil belajar siswa (i). Hasil belajar dengan penggunaan handout lebih bagus disebabkan dengan adanya handout maka siswa (i) akan lebih mudah menguasai materi pembelajaran. Didukung oleh Agustina dkk. (2013) penggunaan metode pembelajaran jigsaw berbantuan handout dapat meningkatkan hasil belajar siswa (i) pada materi pokok hidrokarbon kelas X- C SMA Negeri 1 Gubug. Lebih lanjut, Manik (2012) mengemukakan bahwa penerapan model pembelajaran Make a Match menggunakan handout berpengaruh dalam peningkatan hasil belajar siswa (i) di SMA pada pokok bahasan hidrokarbon.

Data hasil belajar kedua kelas ini dibandingkan berdasarkan tingkat persentase ketuntasan hasil belajar siswa (i) maka yang paling tinggi adalah kelas eksperimen. Hal ini dapat dibuktikan dari analisis data hasil tes masing-masing kelas tersebut. Ada tidaknya perbedaan kedua kelas tersebut di uji dengan menggunakan uji-t. Uji-t dilakukan bertujuan untuk menguji perbedaan signifikan terhadap hasil belajar siswa (i) pada kelas eksperimen dan kelas kontrol, akan tetapi sebelum melakukan uji t terlebih dahulu melakukan uji normalitas 
data hasil belajar siswa (i) pada masingmasing kelas dengan menggunakan rumus $\chi 2$. Dari hasil perhitungan diperoleh bahwa harga $\chi 2$ hitung untuk kelas eksperimen $=$ 7,20 dan harga $\chi 2$ hitung untuk kelas kontrol $=8,74$ dengan harga $\chi 2$ tabel $=11,07$ pada taraf signifikan 5\%. Dari data tersebut diperoleh bahwa $\chi^{2 h i t u n g} \leq \chi^{2 \text { tabel }}$ sehingga dinyatakan data berdistribusi normal.

Data hasil belajar siswa (i) kelas eksperimen dan kelas kontrol juga perlu di uji homogenitas, karena untuk melakukan uji-t selain tergantung pada jumlah sampel kedua kelas tersebut juga tergantung pada varian homogen atau tidak. Apabila jumlah anggota sampel kedua kelompok sama $(\mathrm{n} 1=\mathrm{n} 2)$ dan varian homogen atau bila $\mathrm{n} 1 \neq \mathrm{n} 2$ dan varian homogen digunakan rumus t-test pooled varian, dengan derajat kebebasan $(\mathrm{dk})=\mathrm{n} 1+\mathrm{n} 2-2$. Jika jumlah sampel kedua kelompok tidak sama $(\mathrm{n} 1 \neq n 2)$ dan varian tidak homogen, maka untuk ini digunakan t- test separated varian, dengan derajat kebebasan (dk) (n1 - 1) dan dk (n2 1) dibagi dua. Berdasarkan kriteria pengujian jika Fhitung $\leq$ Ftabel maka dinyatakan varian kedua kelas tersebut homogen. Berdasarkan hasil uji homogenitas data hasil belajar siswa (i) terhadap kedua kelas diperoleh harga Fhitung $=1,646$ harga Ftabel $=1,96$. Hasil uji homogenitas kedua kelas diperoleh varian homogen dan jumlah sampel kedua kelas berbeda maka untuk melakukan uji-t dengan menggunakan rumus pooled varian.

Berdasarkan perhitungan uji-t, diperoleh harga thitung $=3,11$ kemudian harga thitung dibandingkan dengan harga ttabel pada derajat kebebasan $\mathrm{dk}=(\mathrm{n} 1+\mathrm{n} 2$ $-2), \mathrm{dk}=26+24-2, \mathrm{dk}=48$ pada $\alpha 5 \%(\alpha$ $0,05)$. Dari hasil tersebut dapat disimpulkan bahwa harga thitung $\geq$ harga ttabel maka hipotesis yang diajukan diterima yaitu ada terdapat perbedaan yang signifikan hasil belajar siswa (i) kelas kontrol dengan kelas eksperimen pada materi kelarutan dan hasil kali kelarutan siswa (i) kelas XI (MIA) SMAN 6 Banda Aceh. Hal ini didukung oleh Paisal (2007) bahwa pengaruh pemberian handout dalam meningkatkan hasil belajar matematika siswa (i) cukup signifikan. Lebih lanjut Siregar (2013) menyatakan bahwa nilai rata-rata hasil belajar kelas eksperimen lebih tinggi dibandingkan dengan kelas kontrol yang berbeda secara signifikan, sehingga disimpulkan bahwa pembelajaran dengan model pembelajaran kooperatif tipe Numbered Head Together berbantuan handout dapat meningkatkan hasil belajar fisika siswa SMAN 7 Padang. Penemuan peneliti dalam penelitian ini yaitu pemberian handout pada materi kelarutan dan hasil kali kelarutan sangat berpengaruh pada hasil belajar siswa. Hal ini dibuktikan dengan hasil belajar kelas eksperimen lebih tinggi dari pada kelas kontrol. Hal ini dapat menjadi patokan bahwa implementasi bahan ajar dala suatu pembelajaran dapat mendorong motivasi belajar siswa sehingga akan memberikan peluang yang besar terhadap ketercapaian tujuan belajar. Pembelajaran ilmu kimia sangat diharapkan dapat mencapai tujuan akhir secara efektif, sehingga implementasi bahan ajar lain yang lebih komplit sangat diharapkan. Dalam penelitian ini handout pada konsep kelarutan dan hasil kali kelarutan dapat dijadikan salah satu strategi pembelajaran dalam meningkatkan hasil belajar siswa dan diharapkan ada penyempurnaan oleh penyusun berikutnya terhadap handout yang telah dibuat oleh peneliti dalam penelitian ini dengan mengoptimalkan penggunaan handout dalam pembelajaran. Penelitian menggunakan handout yang masih sangat terbatas pada materi kelarutan dan hasil kali kelarutan, diharapkan ada penelitian lanjutan untuk materi lain dalam ruang lingkup yang lebih luas.

\section{KESIMPULAN}

Berdasarkan penelitian yang telah dilakukan peneliti pada konsep kelarutan dan hasil kali kelarutan dengan menggunakan handout dapat disimpulkan bahwa implementasi handout dalam proses belajar mengajar membawa implikasi positif terhadap hasil belajar siswa. Hal tersebut terlihat pada perbedaan hasil belajar siswa yang diajarkan dengan menggunakan bahan ajar handout dengan siswa yang diajarkan tanpa menggunakan bahan ajar handout 
pada materi kelarutan dan hasil kali kelarutan kelas XI MIA SMAN 6 Banda Aceh dianalisis dengan menggunakan uji-t. Hasil uji hipotesis menyatakan bahwa handout dapat memberikan pengaruh yang signifikan terhadap hasil belajar siswa, sehingga handout pada konsep kelarutan dan hasil kali kelarutan dapat dijadikan salah satu strategi pembelajaran dalam meningkatkan hasil belajar siswa dan diharapkan ada penyempurnaan oleh penyusun berikutnya terhadap handout yang telah dibuat oleh peneliti dalam penelitian ini dengan mengoptimalkan penggunaan handout dalam pembelajaran. Penelitian menggunakan handout yang masih sangat terbatas pada materi kelarutan dan hasil kali kelarutan, diharapkan ada penelitian lanjutan untuk materi lain dalam ruang lingkup yang lebih luas.

\section{DAFTAR PUSTAKA}

Agustina, E., Nugroho, A., \& Mulyani S. 2013. Penggunaan Metode Pembelajaran Jigsaw Berbantuan Handout Untuk Meningkatkan Aktivitas dan Prestasi Belajar Siswa pada Materi Pokok Hidrokarbon Kelas Xc Sma Negeri 1 Gubug Tahun Ajaran 2012/2013. Jurnal Pendidikan Kimia (JPK), II (4): 6671.

Brahmantara, I.B.G., Santyasa, I.W., \& Tegeh, I.M. 2013. Pengembangan Multimedia Pembelajaran Berbasis Pengetahuan Awal Untuk Mata Pelajaran Fotografi Bagi Siswa Kelas X SMK Ti Bali Global Singaraja. E-Journal Program Pascasarjana Universitas

Pendidikan Ganesha, Vol. 3

Hartati, S. 2013. "Penggunaan Handout Berbasis Konstektual Pada Materi Koloid Di Kelas XI SMA N 5 Banda Aceh Tahun Ajaran 2012/2013". Skripsi tidak diterbitkan. Banda Aceh: Universitas Syiah Kuala.

Majid, A. 2009. Pengembangan Pembelajaran Mengembangkan Kompetensi Guru. Bandung: Remaja
Rosdakarya.

Manik, A. 2012. Pengaruh Penerapan Model Pembelajaran Kooperatif Tipe Make A Match Menggunakan Media Handout Terhadap Hasil Belajar Kimia Siswa Pada Pokok Bahasan Hidrokarbon di SMA. Skripsi Jurusan Kimia Fakultas Matematika Dan Ilmu Pengetahuan Alam. Medan: Unimed.

Siregar, R. W., Djamas, D., \& Nurhayati. 2013. Pengaruh Model Pembelajaran Kooperatif Tipe Numbered Head Together Berbantuan Handout Terhadap Hasil Belajar Fisika Siswa Kelas XI IPA SMAN 7 Padang. Pillar Of Physics Education, I: 7176.

Situmorang, M. 2013. Pengembangan Buku Ajar Kimia Melalui Inovasi Pembelajaran Dan Integrasi Pendidikan Karakter Untuk Meningkatkan Hasil Belajar Siswa. Proseding seminar FMIPA Universitas Lampung, 237 -246.

Situmorang, M \& Situmorang, A.A. 2014. Efektivitas Modul Pembelajaran Inovatif Untuk Meningkatkan Hasil Belajar Pada Pengajaran Laju Reaksi. Jurnal Penelitian Bidang Pendidikan, 20(2): 139 - 147.

Paisal, A. 2007. Pengaruh Pemberian Handout Dalam Meningkatkan Hasil Belajar Matematia Siswa MTs Kelas VII. Skripsi. Jakarta: Universitas Islam Negeri Syarif Hidayatullah.

Wena, M. 2009. Strategi Pembelajaran Inovatif Kontemporer. Jakarta: PT Bumi Aksara. 